\section{Strategi Merespon Pujian Pasangan Suami Istri}

Desi Fitri

Department of Languages and Literatures Universitas Gadjah Mada danudesifitri@gmail.com

\title{
ABSTRAK
}

Hubungan suami isteri menjadi lebih harmonis dengan adanya komunikasi. Terdapat beragam bentuk komunikasi yang digunakan pasangan suami isteri dalam kehidupan suami isteri diantaranya adalah tuturan memuji dan responnya. Tuturan merespon pujian pasangan suami isteri akan menempatkan penutur pada kondisi yang dilematis antara menerima, menolak atau mengalihkan pujian. Dalam situasi ini, penutur dan mitra tutur akan berusaha mengatasi dilema yang dihadapi dengan melakukan beberapa strategi merespon pujian dalam rangka menghidari ketidaknyamanan dan kesalahpahaman. Oleh karena itu, penelitian ini bertujuan mengetahui dan menjabarkan pilihan strategi yang digunakan oleh pasangan suami istri dalam merespon pujian. Instrumen yang digunakan dalam penelitian ini adalah DTC (Discourse Complement Test). Instrumen ini digunakan untuk mempermudah perolehan data. Data berupa pernyataan yang terdiri dari 10 situasi dan disebarkan kepada 35 pasangan suami isteri melalui bantuan google form. Setelah terkumpul data di analisis dan di kelompokkan sesuai teori yang sudah ditemukan oleh peneliti sebelumnya. Hasil analisis memperlihatkan bahwa terdapat tiga strategi makro yang digunakan pasangan suami isteri dalam merespon pujian yaitu, menerima, menolakmdan mengartikan pujian sebagai permintaan. Strategi makro tersebut kemudian dijabarkan kembali kedalam beberapa strategi mikro yang lebih spesifik. Hasilnya, pasangan suamiistri cenderung menanggapi pujian dengan menggunakan strategi makro penerimaan dengan strategi mikro penerimaan dalam bentuk apresiasi seperti senyum, ungkapan terimakasih, ungkapan bahagia dan doa kepada Tuhan.

Kata kunci: respon pujian; strategi; pasangan.

\section{PENGANTAR}

Seorang penutur akan memunculkan berbagai bentuk tuturan untuk menyampaikan aspirasi, perasan, dan ide yang dia miliki dengan orang-orang disekitarnya dalam berbagai bentuk ekspresi kebahasaan. Bentuk ekspresi kebahasaan yang muncul ketika seseorang bertutur dengan pasangannya antara lain adalah tuturan meminta, tuturan memberi, tuturan menolak, dan tuturan memuji, serta tuturan lainnya. Salah satu tuturan yang sering digunakan dalam konteks pasangan suami isteri adalah tuturan memuji. Menurut KBBI (2008: 1112) memuji adalah melahirkan kekaguman dan penghargaan kepada sesuatu (yang dianggap baik, indah, gagah berani, dsb). Memuji sebagai sarana menyampaikan penghargaan secara tulus kepada mitra tutur. Asal kata memuji adalah puji yang berarti pengakuan rasa kekaguman dan penghargaan yang tulus akan kebaikan (keunggulan) sesuatu. Tuturan memuji dan responnya merupakan salah satu bentuk dari prinsip kesantuan berbahasa. Leech (1993) menyebutkan ada tujuh maksim yang berkaitan dengan prinsip kesantunan, yaitu: kearifan, kedermawanan, pujian, kerendahan hati, kesepakatan, simpati, dan pertimbangan.

Dalam berinteraksi, pasangan suami isteri perlu memahami cara merespon atau menanggapi pujian dengan benar, hal ini dikarenakan suami isteri mempunyai tanggung jawab bersama untuk menjaga keharmonisan rumah tangga. Pasangan suami isteri juga merupakan bagian dari masyarakat tutur yang berasal dari beragam kebudayaan. Hubungan suami isteri hadir karena adanya janji atau ikatan perkawinan. Dalam pasal 33 Undang-Undang No.1 tahun 1974 tentang Perkawinan, disebutkan bahwa "Suami isteri wajib saling mencintai, hormat menghormati, setia, dan memberi bantuan lahir batin yang satu kepada yang lain". Hal ini sejalan dengan pentingnya memuji dan merespon pujian dengan baik sebagai wujud saling menghormati dan memberi bantuan lahir batin. Cahyadi (2014:143) menyebutkan bahwa memuji isteri merupakan bagian dari cara para suami untuk menguatkan cinta dan kasih sayang diantara mereka. Penelitian tentang tuturan memuji dan 
responnya telah dilakukan oleh beberapa peneliti dengan memandang berbagai aspek yang mempengaruhinya seperti latar belakang budaya, pola bahasa, atribut sumber pujian, serta fungsi dan respon yang diberikan. Pomerantz (1978: 81-82) sebagai peneliti pertama respon terhadap tindak tutur memuji menyatakan bahwa ketika seseorang harus memberikan respon terhadap tindak tutur memuji, mitra tutur berada pada posisi dilema karena mitra tutur tidak boleh menolak pujian namun disisi lain juga tidak boleh menunjukkan sikap memuji diri sendiri (self-praise). Merujuk pada prinsip kesantunan Leech (1993) dalam konteks masyarakat timur, terdapat pertentangan antara maksim persetujuan dan maksim kesederhanaan. Oleh karena itu, penerima pujian menggunakan beberapa solusi strategi untuk mengatasi permasalahan ini. Herbert (1989:79) mengidentifikasi tiga strategi makro yang digunakan dalam merespon pujian, pertama menerima, kedua menolak dan ketiga menginterpasikan pujian sebagai permintaan. Ketiga strategi makro tersebut dibagi lagi kedalam 12 strategi mikro.

Penelitian terkait tindak tutur pujian telah lebih dulu dilakukan oleh beberapa peneliti. Holmes (1986) meneliti tentang pujian dan respon pujian di New Zealand. Penelitian ini melihat fungsi, tindak tutur, prinsip kesopanan berbahasa, dan perbedaan budaya (cross-cultural) dalam kebiasaan memuji. Penelitian ini menemukan frekuensi kemunculan kategori adjektif pujian yang dianalisis secara kuantitatif. Kemunculan adjektif pujian yang paling banyak berturut-turut adalah nice, good, lovely, beautiful, great, neat, wonderful, delicious, pretty, new, smart, gorgeous, not bad, clever, bright, brilliant, excellent, fantastic, fine, cute, classy, cool, impressive. Selanjutnya, pembahasan mengenai respon pujian menghasilkan tiga kategori atau tipe respon pujian, yaitu accept (menerima), reject (menolak), dan deflect/evade (mengalihkan).

Guo, Zhou dan Chow (2012) melakukan penelitian dengan judul "A Variationist Study of Compliment Responses in Chinese". Penelitian ini menerapkan kajian sosiolinguistik dan pragmatik dengan korpus data sebanyak 1190 data tuturan natural pada komunitas tutur di Shanghai. Terdapat beberapa strategi merespon pujian yang dilakukan oleh komunitas tutur di Shanghai dengan adanya perubahan konsep kesopanan berbahasa. Respon pujian dihubungkan dengan variasi sosial mulai dari gender, usia, status sosial, pendidikan, kelas sosial, jarak sosial, dan adanya penggunaan bahasa Inggris.

Rose (2001) melakukan penelitian dengan objek kajian film. Penelitian berjudul "Compliment and Compliment Responses in film: Implication for Pragmatics Research and Language Teaching". Penelitian ini ingin mengetahui bagaimana film merepresentasikan komunikasi manusia dalam kenyataan. Penelitian ini mengambil data dari pujian dan respon pujian yang berasal dari 40 film Amerika. Hasil penelitian menunjukkan bahwa bahasa di film merepresentasikan tuturan yang terdapat dalam kehidupan nyata. Kajian difokuskan dengan menggunakan pisau bedah teori sosiopragmatik. Mukminatien dan

Patriana (2005) dengan judul "Respon Pujian dalam Bahasa Indonesia oleh Dwibahasawan IndonesiaInggris" dalam jurnal Bahasa dan Seni pada tahun 2005. Penelitian ini merupakan penelitian sosiopragmatik yang membahas bagaimana respon pujian oleh dwibahasawan Inggris-Indonesia. Hasil penelitian dwibahasawan Indonesia-Inggris telah menunjukkan gejala menuju bikultural. Respon pujian yang diucapkan telah bervariasi, tidak hanya yang bertipe menolak pujian (disagreement type), tetapi juga yang menerima pujian dengan bentuk komentar lanjutan yang berbeda-beda.

Dari penelitian yang telah disebutkan, beberapa penelitian akan menjadi rujukan yang relevan dan berguna untuk penelitian mengenai respon pujian ini. Beberapa metode dari penelitian di atas dapat digunakan pada penelitian dengan mengambil beberapa kelebihan dari masing-masing penelitian. Dengan demikian, penelitian strategi merespon pujian pasangan suami isteri dalam bahasa Indonesia berbeda dengan penelitian-penelitian sebelumnya. Hal ini dikarenakan penelitian ini memfokuskan pada interaksi pasangan suami isteri yang berbentuk tuturan. Adanya penelitian sebelumnya akan sangat membantu penulis sebagai bahan rujukan dan informasi penting terkait penelitian tentang respon pujian pasangan suami isteri.

Penelitian ini akan difokuskan pada analisis strategi merespon pujian pasangan suami isteri. Tuturan yang akan dianalisis adalah tuturan yang muncul pada konteks interaksi suami dan isteri dalam kehidupan sehari-hari. Strategi dalam merespon pujian dengan pendekatan sosiolinguistik dan 
pragmatik (sosiopragmatik). Konteks dan teks dalam tuturan respon pujian yang muncul akan dianalisis menggunakan identifikasi strategi merespon yang telah disampaikan oleh Herbert (1989:79). Sampel data diambil dari 35 pasangan suami istri menggunakan metode purposive sampling. Responden diambil dari pasangan suami isteri terdidik dan dapat mengoperasikan gawai. Hal ini dilakukan karena data diambil dengan bantuan aplikasi. Metode pengumpulan data berbentuk tes melengkapi wacana atau disesbut dengan format DCT (Discourse Completion Test) yang terdiri dari 10 situasi antara penutur dan mitra tutur yang berhubungan dengan kehidupan pasangan suami istri. Responden akan diminta mengisi kolom yang kosong pada wacana situasi yang disediakan. Hal ini dimaksudkan agar responden dapat memberikan tuturan-tuturan pujian secara alami sesuai dengan kondisi nyata dalam kehidupan sehari-hari. Teknik pengumpulan data dilakukan dengan menggunakan bantuan Google form. Untuk memastikan data sesuai dengan data bahasa alami, peneliti melakukan wawancara kepada beberapa responden secara acak untuk mengkonfirmasi jawaban yang sudah diberikan.

\section{ANALISIS DAN PEMBAHASAN}

\section{Analisis}

Hasil analisis data memperlihatkan bahwa dalam memberikan respon terhadap sebuah tindak tutur pujian, suami atau isteri menerapkan beberapa strategi sebagaimana diungkapkan oleh Herbert (1986) dengan beberapa modifikasi. Salah satu contohnya adalah ketika strategi menerima dengan memberikan token apresiasi, suami isteri tidak hanya menggunakan frasa terima kasih. Frasa ini akan diikuti dengan frasa atau klausa lain yang secara eksplisit menyatakan sikap penutur untuk menambah daya terima terhadap sebuah pujian. Ragam strategi yang diterapkan dalam merespon tindak tutur pujian pasangan suami isteri dijabarkan dari DTC dan selanjutnya ditabulasikan kedalam tabel berikut.

Tabel.1

\begin{tabular}{|c|c|c|c|c|}
\hline \multirow[t]{2}{*}{ No } & \multirow{2}{*}{$\begin{array}{l}\text { Ketegori } \\
\text { Respon }\end{array}$} & \multirow[t]{2}{*}{ Strategi Respon } & \multicolumn{2}{|c|}{ Jumlah tuturan } \\
\hline & & & $\begin{array}{l}\text { Dalam } \\
\text { angka }\end{array}$ & $\begin{array}{l}\text { Dalam } \\
\%\end{array}$ \\
\hline 1 & $\begin{array}{l}\text { Menerima } \\
(83,69 \%)\end{array}$ & Memberikan apresiasi & 139 & 39,71 \\
\hline 2 & Memuji balik & 36 & 10,28 & \\
\hline 3 & Menguatkan pujian & 36 & 10,28 & \\
\hline 4 & Memberi komentar & 40 & 11,42 & \\
\hline 5 & Mengalihkan pujian & 42 & 12 & \\
\hline 6 & $\begin{array}{l}\text { Menolak } \\
(7,65 \%)\end{array}$ & $\begin{array}{l}\text { Menolak dengan } \\
\text { merendahkan diri }\end{array}$ & 18 & 2,57 \\
\hline 7 & Mempertanyakan ketulusan & 9 & 1,14 & \\
\hline 8 & $\begin{array}{l}\text { Menunjukkan ketidak } \\
\text { setujuan }\end{array}$ & 4 & 2,8 & \\
\hline 9 & $\begin{array}{l}\text { Menolak dengan } \\
\text { mengabaikan }\end{array}$ & 7 & 1,14 & \\
\hline 10 & $\begin{array}{l}\text { Meresespon } \\
\text { sebagai } \\
\text { permintaan } \\
(5,41)\end{array}$ & Meminta & 10 & 2,85 \\
\hline 11 & Bertanya & 4 & 1,14 & \\
\hline 12 & Tidak ada respon & 5 & 1,42 & \\
\hline
\end{tabular}

Dari tabel di atas dapat dilihat persentase strategi merespon pujian pada pasangan suami isteri. Respon menerima pujian dengan strategi memberikan apresiasi $(39,71 \%)$, memuji balik (10,28\%), menguatkan pujian (10,28\%), memberi komentar (11,42\%) dan mengalihkan

pujian (12\%). Total respon menerima pujian pada pasangan suami isteri berada pada urutan teratas dengan total $83,69 \%$. Untuk kategori menolak pujian persentase yang muncul hanya $7,65 \%$ dan strategi merespon pujian sebagai permintaan menjadi strategi yang sering jarang digunakan karena berada pada urutan ketiga yaitu 5,41\%. 


\section{Pembahasan}

\section{a. Menerima Pujian}

Subkategori menerima dengan memberikan apresiasi

Penutur memberikan tanggapan pujian dengan memberikan jawaban secara verbal dengan menggunakan token apresiasi berupa frasa "terima kasih". Strategi ini dapat dilihat pada paparan di bawah ini. Contoh respon pujian dengan strategi menerima dengan memberikan apresiasi dapat dilihat pada contoh data berikut.

Data 1

Situasi 7: Pasangan Anda baru saja mendapatkan penghargaan atas dedikasinya di pekerjaan. Pujian apa yang Anda berikan pada pasangan?

$P_{1}$ : Woaahhh...keren...Ayah keren bgt ...kok bisa sih ayh pinter gitu...waahhhhh seneng bunda...yang penting ayh yg amanah ya.. (Wah, keren, Ayah keren baget. Kok bisa sih Ayah pintar begitu. Wah, senang Bunda. yang Penting Ayah yang amanah ya!)

$\mathrm{P}_{2}$ : lya dong bun, semua berkat doa bunda n anak2, dan dukungan bunda,,trimakasih y bun udah ngertiin kerjaan ayah,semakin kesini tanggung jawab ayh semakin besar,semoga bunda tmbh lbh ngerti lg. (lya dong Bun, semua berkat doa Bunda dan anak-ana, dan dukungan Bunda. Terimakasih ya Bunda, sudah ngertiin pekerjaan Ayah. Semakin kesini tanggung jawab Ayah semakin besar, semoga Bunda tambah negerti lagi).

Data 2

Situasi 4: Anda hidup bersama pasangan dan sudah melewati waktu yang cukup lama, melewati suka dan duka serta saling mendukung. Pujian apa yang Anda berikan pada pasangan karena hal tersebut?

$\mathrm{P}_{1}$ : Maturnuwun sudah menjadi bagian terindah dalam hidupku (terimakasih sudah menjadi bagian terindah dalam hidupku.

P2: Terimakasih sudah mau menjadi isteriku.

Dari data diatas dapat dilihat bahwa respon menerima pujian merupakan upaya dari pemenuhan terhadap prinsip kesantunan submaksim kesetujuan yang akan memaksimalkan kesetujuan antara diri sendiri dan pihak lain sebanyak mungkin. Ucapan menerima pujian oleh P2 diujarkan melalui frasa penerimaan dan terimakasih. Frasa ini, kemudian, diikuti oleh ujaran yang menunjukkan bahwa P2 menerima pujian tersebut secara terbuka, tetapi dia mengurangi kadar penerimaan itu dengan menyebutkan adanya kontribusi pihak kedua. Kalimat 'berkat doa Bunda' bermakna P 2 menaikkan posisi P1 sebagai orang yang berperan dalam keadaan dia sekarang. Ini bisa dimaknai nilai positif yang sekarang melekat pada $\mathrm{P}_{2}$ menjadi ada karena doa yang diberikan $\mathrm{P}_{1}$ kepada $\mathrm{P}_{2}$. Apresiasi $\mathrm{P}_{2}$ terhadap $\mathrm{P}_{1}$ merupakan usahanya mengurangi daya pujian dan membelokkannya dengan menjadikan orang lain; dalam hal ini mitra tutur, sebagai pihak yang layak mendapatkan apresiasi. Dengan cara ini, P2 sedang mematuhi prinsip kesantunan maksim persetujuan dan sekaligus maksim kerendahan hati.

Subkategori menerima dengan memuji balik

Penutur memberikan tanggapan tindak tutur memuji dengan memuji balik. Strategi ini dapat dilihat pada paparan data 3 di bawah ini.

Data 3

Situasi 7: Pasangan Anda baru saja mendapatkan penghargaan atas dedikasinya di pekerjaan. Ujian apa yang anda berikan pada pasangan?

P1: Keren, selamat Yah.

P2: Makasih, nggak bisa kayak gini juga kalau nggak ada dukungan dari Ibu.

Respon $\mathrm{P}_{2}$ memuji balik pada $\mathrm{P}_{1}$ dengan mengatakan "makasih, nggak bisa kayak gini kalau nggak ada dukungan dari Ibu" merupakan usaha pasangan dalam hal ini suami untuk menaikkan 
status isteri sama dengan dirinya. Dengan demikian, dia berusaha membuat isteri yang memuji ikut merasa senang dan merasa sama. Dengan cara ini, $\mathrm{P}_{2}$ mengurangi potensi dirinya mendapatkan penilaian sebagai pihak yang diuntungkan dengan pujian tersebut. Dengan memberikan pujian pada $\mathrm{P}_{1}$, suami menaikan posisi isteri sebagai orang yang ikut berperan dalam kesuksesan yang ia raih. Pemenuhan maksim keperkenanan submaksim maksimalkan pujian kepada pihak lain digunakan $\mathrm{P} 2$ untuk mengurangi daya terima pujian yang ada padanya.

Subkategori menerima dan menguatkan pujian

Penutur menerima pujian dan memberikan tambahan terhadap daya ilokusi pujian. Strategi ini dapat pada paparan data 4 di bawah ini.

Data 4

Situasi 8. Pasangan Anda baru keluar dari rumah sakit setelah menjalani perawatan beberapa waktu, Anda menemani pasangan hingga la pulih. Pujian apa yang Anda berikan pada pasangan saat kondisi ini terjadi?

P1: Wah sudah kuat lagi nih..

P2: lya donk, si perkasa datang lagi (sambil mrngangkat kedua tangan memamerkan ototnya)

Respon dengan cara menguatkan daya pujian sebagaimana yang dilakukan $\mathrm{P}_{2}$ adalah respon yang sangat mungkin terjadi pada percakapan dimana hubungan antara $\mathrm{P}_{1}$ dan $\mathrm{P}_{2}$ sangat dekat sekali, sehingga $P_{2}$ tidak merasa sungkan untuk memberikan ujaran yang justru menguatkan daya terima pujian. Dengan menunjukkan persetujuan dengan apa yang dinyatakan oleh $\mathrm{P}_{1}$ bukan berarti hal ini bertentangan dengan prinsip kesantunan. Ada dua kondisi yang mengakibatkan $\mathrm{P}_{2}$ bersikap demikian. Faktor penyebabnya bisa jadi pasangan sedang bercanda dengan tututran dan tindakan memamerkan otonya. Gerakan yang dilakukan merupakan salah satu cara untuk mengurangi daya penerimaan terhadap pujian dan sekaligus mengurangi kesan memuji diri sendiri. Kedekatan pasangan juga dapat diperlihatkan lewat cara P2 menerima pujian dengan senang hati. Sikap $\mathrm{P}_{2}$ yang menjadikan mitra tutur menjadi bagian dari diri penutur merupakan pemenuhan terhadap prinsip kesantunan muka positif.

\section{Subkategori menerima dan memberikan komentar}

Penutur memberikan pendapat terhadap objek pujian, terutama penjelasan yang berkaitan dengan bagaimana dia memperoleh objek pujian. Strategi ini dapat dilihat pada paparan data pada situasi 4: Anda hidup bersama pasangan dan sudah melewati waktu yang cukup lama, melewati suka dan duka serta saling mendukung. Pujian apa yang Anda berikan pada pasangan karena hal tersebut?

$\mathrm{P}_{1}$ : Trimakasih ya Yah, Ayah selalu ada buat Bunda, Ayah selalu mendukung Bunda menjadi ibu rumah tangga, Ayah selalu mencukupi kebutuhan kita, Ayah segalanya buat Bunda dan anak-anak. I love you Yah.

P2: Alhamdullillah... Terimakasih dengan Allah SWT Bun, Ayah seneng bunda jadi Ibu rumah tangga dan menemani Ayah dan selalu ada buat anak-anak. Mengajari anakanak agama, yang penting satu saja sama Ayah, Bunda harus nurut. I love you too Bun.

Percakapan diatas menggambarkan bahwa $\mathrm{P}_{2}$ menerima pujian dari $\mathrm{P}_{1}$. Respon menerima pujian dapat dilihat dari kata terimakasih, dilanjutkan dengan mengomentari pujian yang diberikan. Alasan-alasan mengapa pujian itu diterima dan harapan $\mathrm{P}_{2}$ kepada pasangannya. Sikap ini menunjukan bahwa $\mathrm{P}_{2}$ menerima pujian yang diberikan namun mengalihkan pujian dengan mengarahkan $\mathrm{P}_{1}$ untuk berterimakasih pada Allah SWT. Sikap ini menunjukkan bahwa $\mathrm{P}_{2}$ mengalihkan pujian kepada Allah SWT dalam rangka merendahkan diri dan menyadari adanya peran Tuhan dalam kebahagiaanya di rumah tangga. Penutur saling menjaga prinsip kesantunan muka positif dangan memberikan jawaban kasih saying dengan menjawab ujaran "I love You too" untuk memperkuat respon pujian yang telah diberikan. Hal ini tentunya akan meningkatkan daya terima pujian yang diberikan. Dan meningkatkan prinsip kerjasama peserta tutur. 
Menerima pujian dan mengalihkan pujian ke orang lain

Penutur menerima pujian, tetapi dia mengalihkan daya pujian tersebut kepada orang lain. Strategi ini terlihat pada situasi 3. Anda hidup bersama pasangan Anda di rumah mertua Anda. Anda sangat akrab dengan mertua Anda dan pasangan Anda menyukai hal tersebut. Pujian apa yang Anda berikan karena hal ini?

$P_{1}$ : Wah.. menantu kesayangan nih.

P2: Beruntungnya aku punya mertua seperti Ibu dan Bapak Mas.

Ujaran P 2 "beruntungnya aku" merupakan strategi menolak pujian secara tidak langsung. Dengan strategi kesantunan ini, $P_{2}$ sedang berusaha untuk menjaga perasaan atau muka positif $\mathrm{P}_{1}$ dengan mengurangi daya penolakan terhadap pujian yang diberikannya. Ini juga merupakan usaha $\mathrm{P}_{1}$ untuk menghindar dari kesan senang dengan pujian (self-praise) yang diyakini bernilai negatif. Selain menolak pujian secara tidak langsung, $P_{1}$ juga berusaha untuk mengalihkan pujian kepada orang lain yang sedang tidak ada dalam percakapan tersebut dan dalam hal ini adalah mertua $P_{1}$. dalam merespon pujian diatas $P_{2}$ menyampaikan bahwa seharusnya $P_{2}$ yang merasa bahagia memiliki mertua yang baik. Dengan menyatakan bukan dirinya yang harus dipuji, melainkan orang lain, $\mathrm{P}_{1}$ mencoba bersikap rendah hati dengan memenuhi prinsip kesantunan maksim kerendahan hati submaksim minimalkan pujian pada diri sendiri.

\section{b. Menolak Pujian}

\section{Menolak dengan merendahkan diri}

Penutur tidak bersepakat dengan yang disampaikan penutur. Kemudian, dia akan memberikan penjelasan yang menurunkan nilai objek yang sedang dipuji. Strategi ini dapat dilihat pada paparan data situasi 9: keluarga Anda datang berkunjung ke rumah Anda untuk beberapa waktu dan pasangan Anda menjadi tuan rumah yang baik dengan melayani keluarga Anda dengan sepenuh hati. Pujian apa yang Anda berikan kepada pasangan karena hal tersebut?

$\mathrm{P}_{1}$ : Terimakasih ya Sayang, sudah baik sama keluargaku.

P2: Sama-sama Ayah, Allah kan memerintahkan kita untuk berbuat baik pada tamu, apalagi tamunya masih saudara.

Pada contoh diatas $\mathrm{P}_{2}$ secara eksplisit tidak menolak pujian yang dialamatkan kepadanya. Akan tetapi, dia menunjukkan ketidaksetujuannya dengan kalimat sama-sama Ayah, disertai komentar bahwa apa yang dilakukan adalah sebuah kepatuhan pada perintah Tuhan untuk memuliakan tamu. Menolak pada sebuah pujian merupakan usaha untuk menghindarkan diri dari sikap senang memuji diri sendiri. Sikap ini merupakan pematuhan pada prinsip kesantunan berbahasa maksim kerendahan hati. Pada saat bersamaan, dengan menolak pujian secara tidak langsung, P2 sedang berusaha untuk mengurangi potensi ketidaknyamanan $\mathrm{P}_{1}$ karena penolakan tersebut. Dia sedang melindungi muka positif $\mathrm{P}_{1}$ dengan menerapkan strategi kesantunan positif.

\section{Menolak dengan mempertanyakan ketulusan}

Penutur menolak pujian dengan menanyakan kesungguhan mitra tutur dalam memberikan pujian dan tepat tidaknya pujian tersebut. Strategi ini dapat dilihat pada data situasi 2: Anda kagum saat melihat pasangan Anda mengenakan pakaian yang indah saat menghadiri undangan keluarga, pujian apa yang Anda berikan pada pasangan Anda?

$P_{1}$ : Keren Yang.

P2: Masak se? Beneran ta? (Masak sih? Yang benar?).

Pada percakapan dalam situasi diatas dapat dilihat bahwa $\mathrm{P}_{2}$ terlihat pesimistis. Sikap ini ditunjukkan melalui tuturan lya ta? "Masak sih" dan merupakan salah satu cara untuk melindungi muka negatif $\mathrm{P}_{1}$. Penutur $\mathrm{P}_{2}$ menggunakan tuturan yang mengandung makna keraguan sebagai cara dia untuk tidak menerima pujian secara terbuka. Dengan strategi ini, potensi negatif akan adanya anggapan memuji diri sendiri dan menolak pujian bisa diminimalkan sampai pada kadar yang bisa diterima. Kedekatan pasangan suami isteri memungkinkan munculnya respon 
menanyakan ketulusan pemberi pujian. Selain sebagai bentuk penolakan secara terbuka hal ini juga dapat bertujuan untuk meyakinkan P2 bahwa penampilannya benar-benar sesuai harapan.

\section{Menolak dengan menunjukkan ketidaksetujuan}

Penutur menolak pujian dengan menyebutkan bahwa pujian objek yang menjadi pujian merupakan sesuatu yang tidak layak untuk diapresiasi secara positif. Strategi ini dapat dilihat pada paparan data pada situasi 7: Pasangan Anda baru saja mendapatkan penghargaan atas dedikasinya di pekerjaan. Ujian apa yang anda berikan pada pasangan?

$\mathrm{P}_{1}$ : Alhamdulillah. Ayah hebat.

P2: Biasa saja. Yuk kita makan diluar bersama anak-anak.

P2 pada tuturan di atas menolak pujian yang dialamatkan kepadanya dengan menggunakan ujaran yang secara tersurat mewakili sikapnya dengan respon "Biasa saja". Ujaran ini bisa memberikan efek yang tidak baik pada $\mathrm{P}_{1}$ karena muka positifnya sedang dilanggar ketika $\mathrm{P}_{2}$ tidak bersepakat atau setuju terhadap pandangan $\mathrm{P}_{1}$ bahwa $\mathrm{P}_{2}$ mempunyai kemampuan untuk melakukan sesuatu yang mendatangkan pujiannya. Sadar dengan potensi ini, kemudian, P2 berusaha untuk memperhalus penolakannya terhadap pujian $\mathrm{P}_{1}$ dengan mengujarkan "Yuk kita makan diluar". Dengan ujaran ini, $\mathrm{P}_{2}$ sedang bersikap rendah hati dengan cara menjelaskan bahwa apa yang sedang dikerjakannya merupakan kegiatan yang kurang bernilai. Dengan cara ini, sebenarnya $\mathrm{P} 2$ sedang melakukan dua tindak secara bersamaan, yaitu menjaga muka positif mitra tutur dan memenuhi prinsip kesantunan submaksim meminimalkan pujian pada diri sendiri.

\section{Menolak dengan mengabaikan}

Penutur tidak menunjukkan indikasi kalau dirinya mendengar pujian dengan memberikan tanggapan yang tidak relevan atau tidak menanggapi sama sekali. Strategi ini dapat dilihat pada paparan data situasi 10: Anda beberapa waktu tidak dapat bertemu denagan pasangan karena sesuatu (pekerjaan, ibadah, atau tugas kantor) saat bertemu kembali, pujian apa yang Anda berikan pada pasangan?

$\mathrm{P}_{1}$ : Terimakasih ya Sayang, sudah mengijinkan kegiatan luar kota dan sudah sabar menemani anak-anak.

P2: Lain kali kalau kegiatan sudah selesai langsung pulang.

Menolak pujian dengan mengabaikan terjadi manakala $\mathrm{P}_{2}$ secara sengaja tidak memberikan tanggapan yang sesuai dengan ilokusi pujian. Di dalam percakapan di atas, P3 memberikan respon pujian dengan ujaran "lain kali kalau kegiatan sudah selesai langsung pulang" kurang relevan dan tidak menjawab tuturan yang disampaikan oleh $\mathrm{P}_{1}$. Cara menjawab $\mathrm{P}_{2}$ bisa diartikan dalam beberapa makna. Makna pertama adalah bahwa dia sedang tidak kooperatif dengan $\mathrm{P}_{1}$ dan makna kedua, adalah bahwa dia sedang berusaha untuk menghindarkan diri dari kesan menerima pujian secara terbuka. Jika dilihat bahwa sebenarnya $\mathrm{P} 2$ kooperatif dalam percakapan tersebut, makna kedua menjadi interpretasi yang lebih tepat. Dengan cara ini P2 berusaha untuk memenuhi maksim kerendahan hati submaksim minimalkan pujian pada diri sendiri. Artinya $\mathrm{P}_{2}$ berusaha meminimalkan kesan kalau dirinya sedang menerima pujian dengan senang hati.

\section{c. Memaknai Pujian sebagai Permintaan}

Di dalam menanggapi sebuah tindak tutur respon pujian, penutur terkadang memaknainya sebagai sebuah permintaan, sehingga tanggapan yang diberikan oleh penutur adalah memberikan respon positif atau menolak pujian yang diberikan. Strategi ini dapat dilihat pada paparan data di bawah ini.

\section{Merespon pujian dengan meminta.}

Respon pujian dengan strategi meminta dapat dilihat pada situasi 6: Anda akan mendapatkan buah hati setelah berjuang bersama-sama untuk mendapatkannya. Pujian apa yang Anda berikan kepada pasangan?

$\mathrm{P}_{1}$ : Alhamdulillah ya Mas, semoga Allah selalu melindungi kita semua. 
P2: Aamiin. Sayang jaga kesehatan yaa. Jangan kecapean!

Data diatas memperlihatkan bahwa respon pujian seiring dengan tuturan pujian yang diberikan. Dengan ujaran "aamiin" lalu diikuti oleh permintaan pasangan agar isteri yang mengandung menjaga kesehatan dan tidak kelelahan selama proses berlangsung. Hal ini menunjukan adanya harapan kedua pasangan agar kehamilan dan proses ini lancar. Pujian yang diberikan lebih menitikberatkan pada ungkapan rasa syukur kepada Tuhan.

\section{Merespon Pujian dengan bertanya}

Pujian yang diberikan seseorang dapat direspon dengan pertanyaan tergantung situasi yang berlangsung. Strategi merespon pujian dengan bertanya dapat menjadi pilihan mitra tutur dalam membangun kedekatan dan muka positif. Hal ini dapat dilihat dalam situasi 1: ketika pertama kali Anda melihat pasangan Anda mengenakan pakaian pengantin, pujian apakah yang Anda berikan pada pasangan Anda?

$$
\begin{aligned}
& \mathrm{P}_{1} \text { : Kamu cantik menawan memakai gaun itu. } \\
& \text { P2: apakah ini nyata atau mimpi ya? }
\end{aligned}
$$

Data di atas menggambarkan respon pujian berupa pertanyaan. Hal ini bisa bermakna $\mathrm{P}_{2}$ menerima pujian namun ingin menyatakan apa yang dialami dan yang dikenakan adalah hal di idam-idamkan. Tuturan yang muncul dapat juga bermakna P2 menerima pujian namun secara tidak langsung menanyakan apakah yang memuji juga merasakan hal yang sama seperti dirinya. $\mathrm{Hal}$ ini memenuhi maksim kerendahan hati dan mengurangi pujian bagi diri sendiri.

\section{Merespon sebagai permintaan subkategori tidak ada respon.}

Terdapat strategi merespon pujian sub kategori tidak ada respon yang di latarbelakangi oleh beberapa faktor. Bisa saja penutur tidak mendengar pujian yang diberikan, atau penutur tidak menangkap maksud dari tuturan yang diberikan. Data di dapatkan dari situasi 2: Anda kagum saat melihat pasangan Anda mengenakan pakaian yang indah saat menghadiri undangan keluarga, pujian apa yang Anda berikan pada pasangan Anda?

$\mathrm{P}_{1}$ : Nah, gitu lah tampanan dikit, sekali-kali rapi kan enak dilihat.

P2:(tidak ada respon)

Tindak tutur memuji seringkali diartikan dengan bentuk tindak tutur lain. Sebagaimana terlihat pada data di atas, respon pujian tidak langsung disampaikan kepada mitra tutur lewat ujaran. Kebisuan mitra tutur bisa jadi menolak atau menerima. Pujian yang diberikan pada data diatas bisa saja tidak benar-benar ingin memuji mitra tutur, namun bisa diartikan lain bagi penerimanya. Sehingga tidak ada respon bisa jadi menjadi strategi yang tepat dalam menanggapi pujian yang diberikan. Hal ini dapat dikategorikan dalam maksim kebijaksanaan.

\section{KESIMPULAN}

Pasangan suami isteri sangat mudah dalam memberikan pujian karena dalam hubungan tersebut pujian akan memberikan rasa kekaguman dan perasaan dihargai oleh pasangan. Pujian menjadi salah satu sarana untuk menjalin dan meningkatkan keharmonisan hubungan. Dengan pujian, pasangan dapat mengawali dan membuka percakapan sebagai suatu bentuk tindakan yang mewakili sikap seseorang yang punya itikad baik untuk menjalin komunikasi. Mudahnya pasangan memberikan pujian tidak sama dengan Ketika mereka harus menerima pujian. Menerima pujian merupakan aspek yang sangat berbeda. Kesalahan dalam merespon pujian akan menjadikan pujian yang diberikan tidak sesuai dengan harapan. Tujuan memuji yang tadinya disampaikan secara tulus dapat menjadi bumerang jika di respon secara tidak tepat. Kedekatan pasangan juga mempengaruhi daya terima pujian. Diperlukan adanya perasaan saling memahami dan menghindari saling curiga. Pemahaman untuk berbagi beban dan berbagi kebahagiaan menjadi faktor yang membuat mereka berhati-hati di dalam memberikan respon sebuah pujian. Kehati-hatian ini tercermin dalam strategi yang mereka gunakan. 


\section{DAFTAR PUSTAKA}

Chen Rong. 1993. Responding to Compliments: A Contrastive Study of Politeness Strategies between American English and Chinese Speakers. Journal of Pragmatics 20: 49-75

Cordello, M.H Large\&V. Pardo. 1995. Complimenting Behavior in Australian English and Spanish Speech. Multilingua 14 (3): 235-252

Daikuhara, Misato. 1986. A Study of Compliments from A Cross-Cultural Perspective: Japanese vs American English. WPEL: Working Papers in Educational Linguistics, 2 (2), 103-134

Holmes, Janet. 1988a. Compliment and Compliment Responses in New Zealand. Anthropological linguistics. 28 (4): 485-508

Leech, Geoffrey N. 1993. Prinsip-Prinsip Pragmatik. Alih bahasa oleh M.D.D Oka. Jakarta: UI Press

Oktiva Herry Chandra, Marsono, Suhandano,.2019. Menanggapi Pujian dalam Bahasa Jawa di Semarang. NUSA, Vol. 14 No. 2 Mei Pomerantz, Anita. 1978. Compliment Responses: Notes on The Cooperation of Multiple Constraints. Studies in the Organization of Conversational Interaction, Ed. By J. Schenkein. New York

Rosiah. Rosi. 2018. Strategi Merespon Pujian Pada Pembelajar Bahasa Jepang: Kajian Komparatif Dengan Penutur Asli. Jurnal Lingua Aplicata Volume 1, Nomor 2 Maret Takariawan, Cahyadi. 2014. Wonderful Family: Merajut Keindahan Keluarga. PT Adicitra Intermedia. Solo

Undang-Undang Nomor 1 Tahun 1974 Tentang Perkawinan. 